\title{
Cutaneous Glomangioma
}

National Cancer Institute

\section{Source}

National Cancer Institute. Cutaneous Glomangioma. NCI Thesaurus. Code C6750.

A glomus tumor arising from the skin. It is characterized by the presence of dilated veins surrounded by glomus cells. 